\title{
An Economic Analysis of Black-tailed Prairie Dog [Cynomys ludovicianus] Control
}

\author{
ALAN R. COLLINS, JOHN P. WORKMAN, AND DANIEL W. URESK
}

\begin{abstract}
Black-tailed prairie dog (Cynomys ludovicianus) control by poisoning with zine phosphide was not economically feasible in the Conata Basin of South Dakota. Economic analyses were conducted from U.S. Forest Service and rancher viewpoints. Control programs were analyzed with annual maintenance or complete retreatment of initially treated areas to prevent prairie dog repopulation and, except for annual maintenance at low repopulation rates, were unable to recover initial control costs. At a prairie dog repopulation rate of $30 \%$ per year (the most realistic projection), prairic dog control was not economically feasible and annual maintenance control costs were greater than the annual value of forage gained. Control benefit was forage gained on treated areas. With an increase of approximately $51 \mathrm{~kg} / \mathrm{ha}$ of cattle forage, over 7 ha of initial prairie dog control were required to gain 1 AUM per year for the life of the treatment.
\end{abstract}

Prairie dogs have been controlled on western rangelands for many years (Merriam 1902), yet there has never been an economic analysis of any control method. While control has sometimes been justified on the basis of reducing the potential of a plague outbreak among prairie dog populations, competition between domestic livestock and prairie dogs for range forage has been the main justification for control. Research efforts have investigated this competition (Taylor and Loftfield 1924, Hansen and Gold 1977), but no effort has been made to evaluate the costs and benefits of eliminating or decreasing prairie dog populations.

Early literature on prairie dog-livestock competition was negative. Merriam (1902) and Bell (1920) described losses in crops and range forage due to prairie dogs and recommended prairie dog elimination. In northern Arizona, Zuni prairie dogs (C. gunnisoni zuniensis) reportedly consumed $80 \%$ of the total annual forage production and seriously competed with cattle for available forage, especially during droughts (Taylor and Loftfield 1924).

Recent information suggests that black-tailed prairie dogs (Cynomys ludovicianus) compete with cattle for forage, but possibly not enough to warrant control measures (Klatt and Hein 1978). Most plants consumed by black-tailed prairie dogs are potential cattle forage (Kelso 1939, Bonham and Lerwick 1976). Summers and Linder (1978) stated that important food species for blacktailed prairie dogs in the Conata Basin of South Dakota were buffalograss (Buchloe dactyloides), scarlet globemallow (Sphaeralcae coccinea), threadleaf sedge (Carex filifolia), blue grama (Bouteloua gracilis), and western wheatgrass (Agropyron smithii). Hansen and Gold (1977) found sedges made up the largest percentage of the diet for black-tailed prairie dogs in northeastern Colorado and the second largest percentage in cattle diets. In their study, cattle and prairie dog diets were most similar during spring. Hansen and Gold (1977) estimated that prairie dogs consumed

Ut
Research Laboratory, South Dakota School of Mines and Technology, Rapid City
57701 . A. Collins is now research associate, Division of Agricultural Economics,
University of Wyoming, Laramie 82071 .
Manuscript accepted September 26,1983 .

about $53 \mathrm{~kg} / \mathrm{ha}$ of potential cattle forage and attributed a $100-$ $\mathrm{kg} /$ ha decline in plant production to denudation around prairie dog mounds.

O'Meilia et al. (1982) found no significant difference in annual steer weight gains on pastures with black-tailed prairie dogs compared to pastures without prairie dogs, despite one-third less available forage on pastures with prairie dogs. They reasoned that higher forage quality resulting from prairie dog activities compensated for reduced available forage.

Prairie dog control methods include poisoning as well as grazing management techniques. Snell and Hlavachick (1980) observed that 4 successive years of grazing deferments during the growing season substantially reduced black-tailed prairie dog town size on shortgrass rangeland. Based on burrow counts, black-tailed prairie dog density in the Conata Basin was significantly less on cattle exclosures than on prairie dog colonies grazed by cattle (Uresk et al. 1982). Lastly, an attempt to reduce black-tailed prairie dog populations by reducing forb production with a herbicide did not succeed as prairie dogs switched their diets from forbs to grasses (Fagerstone et al. 1977).

This study provides benefit-cost analyses of prairie dog control by poisoning with zinc phosphide from public land management agency and rancher viewpoints. Data for this study were obtained from a prairie dog control program conducted in the Conata Basin of the Wall Ranger District in South Dakota by the U.S. Forest Service. Forage response data were provided by the Rocky Mountain Forest and Range Experiment Station in Rapid City (Uresk and Bjugstad 1983).

\section{Study Area and Methods}

The study was conducted in the Conata Basin, about $80 \mathrm{~km}$ southeast of Rapid City, S. Dak. Badlands National Mounument is to the north and the Pine Ridge Indian Reservation is on the south border. The Basin has shortgrass vegetation dominated by blue grama and buffalograss with an annual precipitation of 38 to $43 \mathrm{~cm}$.

Prairie dog control was conducted during late summer and fall on the east half of the Buffalo Gap National Grassland, which is administered by the Nebraska National Forest. Cattle graze the area from May to October.

\section{Vlewpoints}

1. The rancher vewpoint was prairie dog control conducted on private lands with no wildlife considerations. The costs of environmental impact statements, black-footed ferret (Mustela nigripes) inventory and reconnaissance, and prairie dog colonies left for ferret habitat were not included in this viewpoint. The U.S. Forest Service actual control costs were assumed to approximate costs of a large scale prairie dog control operation that would be contracted out by a group of ranchers.

2. The U.S. Forest Service was regarded as an agent for society which accounts for direct benefits [Animal Unit Months (AUMs) of forage] and costs (the value of goods and services used in control) within a benefit-cost analysis of prairie dog control. As an 
agent for society, the U.S. Forest Service accounted for all direct benefits without regard to whom they accrue. All costs incurred in a U.S. Forest Service prairie dog control program were accounted for in this viewpoint.

\section{Forage Benefits}

Forage benefits were calculated only on controlled areas. Benefits of preventing the further spread of prairie dogs by poisoning control were not calculated in this study because future prairie dog expansion beyond controlled hectares was deemed too difficult to project. Problems with projection included: where to stop (one could conceivably accrue benefits of preventing the entire Conata Basin from being covered by prairie dog towns) and different types of benefits (tangible versus avoidance of possible losses). Valuation of forage benefits from controlled hectares was a conservative estimate of prairie dog control benefits but accounted for only tangible benefits.

Vegetation production data to measure forage benefits were collected biannually between 1975 and 1980 on: (1) ungrazed (fenced to exclude both prairie dogs and cattle); (2) prairie dog grazing, (fenced to exclude only cattle); and (3) cattle and prairie dog grazing areas (Uresk and Bjugstad 1983). Production sampling on cattle grazing only areas was discontinued after 1977 due to prairie dog invasion. Vegetation utilization was measured only during the last 3 years of the study.

To measure the effect prairie dog control had on vegetation production, production from ungrazed exclosures was compared to production from areas grazed only by prairie dogs. Ideally, vegetation production data should reflect the influence of cattle grazing on both areas. But, these exclosures were used in this study rather than cattle grazing areas versus cattle and prairie dog grazing areas because: (1) prairie dogs had already been eliminated in ungrazed exclosures, (2) 6 years of data were available for the exclosures compared to 3 years for cattle grazing areas, and (3) utilization was measured in conjunction with production for 3 years on areas grazed only by prairie dogs. By comparison, no utilization data were collected in combination with cattle grazing versus cattle plus prairie dog grazing production data.

Five categories of cattle forage were measured for production and utilization (Table 1). Total production was not significantly different $(p>0.05)$ between grazed and prairie dog grazing exclosures. Category production differences were significant $(P<0.05)$ for only needleleaf sedge (Carex eleocharis) and scarlet globemallow.

Because of insignificant production differences, the analysis of forage benefits due to prairie dog control was based only on changes in forage availability due to elimination of prairie dog utilization of plant species. Six-year average plant production under cages in areas grazed by prairie dogs was multiplied by average prairie dog utilization to give estimated $\mathrm{kg} /$ ha consumed annually by prairie dogs for each plant category over the 6-year period. To convert to usable cattle forage, the estimated $\mathrm{kg} / \mathrm{ha}$ consumed by prairie dogs was multiplied by cattle utilization percentages. These cattle use percentages for each forage species (Table 1) were calculated from cattle diet data on the Conata Basin (Uresk unpublished data) at the 1975 stocking rate.

The total change in usable cattle forage was divided into $367 \mathrm{~kg}$ of usable forage required per AUM (Vavra et al. 1977) to give the hectares of control needed to obtain 1 increased AUM of grazing. Forage gain was assumed to begin the grazing season after initial control or retreatment occurred. Immediate benefits were based on the assumption that the only control benefit was elimination of prairie dog utilization of cattle forage species rather than changes in vegetative composition.

Forage benefits from prairie dog control were projected on the basis of 2 methods of controlling prairie dog repopulation: (1) future annual maintenance control to prevent prairie dog repopulation of the control area, and (2) complete retreatment once prairie dogs have repopulated the entire area initially controlled. Annual maintenance control is a projection into the future and the required amount of control is very difficult to forecast. Thus, annual maintenance control was projected at 4 percentages of the total area controlled initially: 5, 10, 20, and 30\%. Complete retreatment of the area initially controlled was forecast to be required every $3,6,9$, and 15 years. Annual forage benefits were assumed to decline at a constant rate due to prairie dog repopulation until they reached zero in the year of retreatment. For each projection, calculations were made for the number of years of project life required to cover initial control costs.

A private market AUM value was used to value increased cattle forage for both viewpoints. The AUM price was set at the value of the forage component of 1979 private lease rates for western South Dakota. The best estimate was a per acre leasing arrangement since per acre lessors generally provide little or no services such as salting, fence maintenance, and herding (Wyoming Crop and Livestock Reporting Service 1979). The South Dakota Crop \& Livestock Reporter estimated a $\$ 6$ per acre cash rent $(\$ 14.80 /$ ha) for rangeland in the western part of South Dakota (USDA 1979). Based on a carrying capacity of 0.8 ha per AUM in the summer, an AUM was worth about $\$ 12$ in 1979.

From the rancher viewpoint, a $\$ 12$ per AUM value can be regarded as the lease rate at which increased forage from control could be leased to another rancher or as the savings of undertaking a control program to avoid leasing forage from another landowner. For the U.S. Forest Service, the entire value of cattle forage gained from prairie dog control was counted as a benefit, the rationale being that forage was made available for use even though its full value was not charged as a fee.

\section{Costs}

Poisoning of prairie dogs was done with zinc phosphide in steam-rolled oats after pre-baiting prairie dog colonies. Annual prairie dog control costs included planning, management, poison-

Table 1. Vegetation production and utilization and cattle forage changes due to prairie dog elimination (mean \pm SE).

\begin{tabular}{|c|c|c|c|c|c|}
\hline \multirow[b]{2}{*}{ Category } & \multicolumn{2}{|c|}{ Production (kg/ha) } & \multicolumn{2}{|c|}{ Utilization (\%) } & \multirow{2}{*}{$\begin{array}{l}\text { Cattle forage change } \\
\text { due to prairie dog } \\
\text { elimination }(\mathrm{kg} / \mathrm{ha})\end{array}$} \\
\hline & Ungrazed ${ }^{1}$ & $\begin{array}{c}\text { Grazed by prairie } \\
\text { dogs }{ }^{2}\end{array}$ & $\begin{array}{c}\text { Prairie dog } \\
\text { utilization }\end{array}$ & $\begin{array}{c}\text { Cattle } \\
\text { utilization }\end{array}$ & \\
\hline $\begin{array}{l}\text { Blue grama and buffalograss } \\
\text { Western wheatgrass and crested }\end{array}$ & $672 \pm 78$ & $704 \pm 77$ & $24 \pm 4$ & $8 \pm 2$ & $14 \pm 0.73$ \\
\hline $\begin{array}{l}\text { wheatgrass } \\
\text { (Agropyron cristatum) }\end{array}$ & $157 \pm 51$ & $112 \pm 28$ & $33 \pm 4$ & $48 \pm 11$ & $18 \pm 1.6$ \\
\hline $\begin{array}{l}\text { Needleleaf sedge (Carex eleocharis) } \\
\text { Other grasses } \\
\text { Scarlet globemallow } \\
\text { TOTALS }\end{array}$ & $\begin{array}{r}203 \pm 33 \\
90 \pm 47 \\
48 \pm 8 \\
1,170 \pm 95\end{array}$ & $\begin{array}{r}92 \pm 14 \\
191 \pm 57 \\
100 \pm 12 \\
1,199 \pm 123\end{array}$ & $\begin{array}{l}38 \pm 9 \\
34 \pm 14 \\
22 \pm 7\end{array}$ & $\begin{array}{r}10 \pm 4 \\
9 \pm 3 \\
39 \pm 11\end{array}$ & $\begin{array}{r}4 \pm 0.2 \\
6 \pm 0.5 \\
9 \pm 0.5 \\
51 \pm 1.94\end{array}$ \\
\hline
\end{tabular}

Cattle and prairie dogs excluded

${ }^{2}$ Cattle excluded

Estimation of SE according to Goodman (1960)

$4 \mathrm{SE}=\sqrt{\mathrm{SE}+\mathrm{SE}-}$ 
Table 2. Prairie dog control costs, two viewpoints, 1978-1980.

\begin{tabular}{lccc}
\hline \hline Viewpoint & 1978 & 1979 & 1980 \\
\hline & \multicolumn{3}{c}{ dollars/ha } \\
Rancher & 16.20 & 11.73 & 12.13 \\
U.S. Forest Service & 17.83 & 13.36 & 13.29 \\
\hline
\end{tabular}

ing, and pre- and post-treatiment monitoring costs (Table 2). All future control control costs were estimated to be $\$ 12 /$ ha for the rancher viewpoint and \$13.50 for the U.S. Forest Service based on 1980 cost figures. The cost of the required U.S. Forest Service environmental impact statement was estimated to be $\$ 15,300$ in 1977 (J.A. Lees, 1980, Range and Wildlife Staff Officer, Nebraska National Forest, Chadron, Neb.).

All costs and benefits in this study were in real (inflation free) terms and discounted with a real discount rate. A 4\% discount rate recommended in the U.S. Forest Service manual for economic and social analysis (USDA Forest Service 1980) was used for both viewpoints. The first year of control (1978) was used as the base year for discounting all future costs and benefits.

\section{Results and Discussion}

Increased cattle forage from prairie dog control was estimated at $51 \mathrm{~kg} /$ ha per year (Table 1). Largest increases came from blue grama-buffalograss and western-crested wheatgrass categories with mean increases of 14 and $18 \mathrm{~kg} / \mathrm{ha}$ respectively. Based on a mean gain of $51 \mathrm{~kg} / \mathrm{ha}, 7.2$ ha of initial prairie dog control were required to gain 1 AUM of grazing annually for the life of the program.

Between 1978 and 1980, 11,810 ha were initially controlled by the U.S. Forest Service (Table 3). Areas that required retreatment were assumed to provide no increased cattle forage. Thus, the 1,027 ha producing increased cattle forage in 1979 resulted from 2,170 ha of initial control in 1978 minus 1,143 ha retreated in 1979 (Table 3).

Table 3. Prairie dog control and forage benefits, 1978-80.

\begin{tabular}{lcccc}
\hline & $\begin{array}{c}\text { Land } \\
\text { controlled } \\
\text { initially } \\
\text { (ha) }\end{array}$ & $\begin{array}{c}\text { Land } \\
\text { retreated } \\
\text { (ha) }\end{array}$ & $\begin{array}{c}\text { Land producing } \\
\text { increased } \\
\text { cattle forage } \\
\text { (ha) }\end{array}$ & $\begin{array}{c}\text { AUMs } \\
\text { gained }\end{array}$ \\
\hline 1978 & 2,170 & 0 & 0 & 0 \\
1979 & 7,312 & 1,143 & 1,027 & 143 \\
1980 & 2,327 & 1,419 & 8,060 & $( \pm 12)^{1}$ \\
& & & & 1,120 \\
& & & & $( \pm 88)$ \\
\hline
\end{tabular}

$195 \%$ confidence intervals for total cattle forage gained due to prairie dog elimination.

The number of hectares producing increased cattle forage were divided by 7.2 ha per AUM to calculate AUM's gained. Hectares of initial control and retreatment were the same for both viewpoints until 1981. At this time, U.S. Forest Service initial control was projected to end while ranchers were projected to initially control an additional 1,800 ha of prairie dog colonies in 1981 that were left by the U.S. Forest Service for black-footed ferret habitat. For the rancher viewpoint, 13,610 ha were controlled initially. Projections for annual maintenance control and complete retreatment for repopulation control began in 1981 for the U.S. Forest Service and in 1982 for the ranchers.

For both viewpoints, only annual maintenance control percentages below $10 \%$ could recover initial prairie dog control program costs (Table 4). Even at a low annual repopulation rate ( $5 \%$ ), mean values of 40 and 22 years of maintenance control were required to recover initial control costs (discounted benefits-discounted costs greater than 0) for the U.S. Forest Service and ranchers, respectively. Annual maintenance of 20 and $30 \%$ of the area initially
Table 4. Annual hectares of control, annual benefits, and years required to recover control costs for four projections of annual maintenance and two viewpoints.

\begin{tabular}{lcccc}
\hline & \multicolumn{4}{c}{ Percentage annual maintenance control } \\
\cline { 2 - 5 } & $5 \%$ & $10 \%$ & $20 \%$ & $30 \%$ \\
\hline $\begin{array}{l}\text { U.S. Forest Service Viewpoint } \\
\text { Maintenance Control (ha) }\end{array}$ & 590 & 1,180 & 2,360 & 3,540 \\
$\begin{array}{l}\text { Forage gained } \\
\text { (AUMs) }\end{array}$ & 1,560 & 1,480 & 1,310 & 1,150 \\
$\begin{array}{c}\text { Annual Net benefits } \\
\text { (dollars) }\end{array}$ & $( \pm 122)^{1}$ & $( \pm 116)$ & $( \pm 104)$ & $( \pm 91)$ \\
Required years to recover & 10,700 & 1,800 & $-16,100$ & $-34,000$ \\
$\quad$ costs & $( \pm 1,500)$ & $( \pm 1,400)$ & $( \pm 1,250)$ & $( \pm 1,100)$ \\
Rancher Viewpoint & 40 & cannot & cannot & cannot \\
Maintenance Control (ha) & $(30-63)^{2}$ & & & \\
$\begin{array}{l}\text { Forage gained } \\
\text { (AUMs) }\end{array}$ & 680 & 1,360 & 2,720 & 4,080 \\
Annual Net benefits & 1,800 & 1,700 & 1,510 & 1,320 \\
$\quad$ dollars) & $( \pm 142)$ & $( \pm 134)$ & $( \pm 120)$ & $( \pm 105)$ \\
Required years to & 13,400 & 4,100 & $-14,500$ & $-33,100$ \\
recover costs & $( \pm 1,700)$ & $( \pm 1,600)$ & $( \pm 1,400)$ & $( \pm 1,250)$ \\
& 22 & cannot & cannot & cannot \\
\hline
\end{tabular}

$195 \%$ confidence intervals for total cattle forage gained due to prairie dog elimination. 'Years to recover costs based on high and low confidence bounds for annual net benefits.

controlled cost more than the annual value of AUM's gained (negative net annual benefits).

Complete retreatment of the area controlled initially would not be economically feasible from either viewpoint for any of the 4 projected retreatment periods (Table 5). Initial control costs could not be recovered before the first retreatment was required nor could they ever be recovered because of discounting future benefits.

The most realistic projection of annual prairie dog repopulation appears to be $30 \%$ of the area controlled initially. Schenbeck (1982) stated that most prairie dog colonies treated in the Conata Basin will need retreatment at least every 3 years. Thus, prairie dog control on the Conata Basin was not economically feasible. Due to the rapid repopulation rate, annual maintenance control costs would be greater than the annual value of AUM's gained.

Benefits from preventing the further spread of prairie dogs were not included in this economic analysis. The value of forage benefits solely from a treated hectare was not sufficient to recover initial control costs under realistic conditions. This means that prairie dog control loses money on each treated hectare, but a control program could possibly be economically feasible if the prevention benefits are considered. The implication, though, is for a diseconomy of scale on prairie dog control programs because smaller

Table 5. Complete retreatment projections from two viewpoints.

\begin{tabular}{lcccc}
\hline & \multicolumn{4}{c}{ Complete retreatment period (yrs) } \\
\cline { 2 - 5 } & 15 & 9 & 6 & 3 \\
\hline $\begin{array}{l}\text { U.S. Forest Service Viewpoint } \\
\text { Total retreatment } \\
\text { cost }=\$ 159,000\end{array}$ & & & & \\
Maximum annual & 18,370 & 17,500 & 16,400 & 13,120 \\
dollar benefit & $( \pm 1,450)^{1}$ & $( \pm 1,380)$ & $( \pm 1,300)$ & $( \pm 1,040)$ \\
Annual decline in dollar & 1,300 & 2,190 & 3,280 & 6,560 \\
benefits & $( \pm 100)$ & $( \pm 170)$ & $( \pm 260)$ & $( \pm 520)$ \\
Years to recover costs & cannot & cannot & cannot & cannot \\
& & & & \\
Rancher Viewpoint & & & & \\
Total retreatment & & & & \\
cost $=\$ 163,000$ & & & & \\
Maximum annual & 21,180 & 20,170 & 18,910 & 15,130 \\
dollar benefit & $( \pm 1,670)$ & $( \pm 1,590)$ & $( \pm 1,490)$ & $( \pm 1,190)$ \\
Annual decline in & 1,520 & 2,520 & 3,780 & 7,570 \\
dollar benefits & $( \pm 120)$ & $( \pm 200)$ & $( \pm 300)$ & $( \pm 600)$ \\
Years to recover costs & cannot & cannot & cannot & cannot \\
\hline
\end{tabular}

$195 \%$ confidence intervals for total cattle forage gained due to prairie dog elimination. 
programs lose less total money which increases the possibility of prevention benefits making up for losses on treated hectares.

Only market priced benefits and costs were used in this analysis. Non-quantifiable or non-market benefits claimed by the U.S. Forest Service from control of prairie dogs included improved range condition, decreased erosion, and protection of private lands from the spread of prairie dogs (USDA 1978). Non-market costs associated with prairie dog control include the loss of prairie dogs for sight-seeing and sport shooting. In addition, there is a loss of black-footed ferret habitat and various benefits to other wildlife associated with prairie dog colonies (O'Meilia et al. 1982). These costs have been mitigated by the U.S. Forest Service through retention of small prairie dog colonies.

\section{Summary and Conclusions}

Black-tailed prairie dog control by poisoning with zinc phosphide was evaluated economically on the basis of forage benefits from treated hectares. Control costs on the Conata Basin could only be recovered at low annual maintenance control rates to prevent repopulation and could not be recovered with projections of complete retreatment of the initially controlled area. Recovery of initial control costs took mean values of 40 and 22 years of maintenance control at a $5 \%$ annual repopulation rate for the U.S. Forest Service and ranchers respectively. Given annual maintenance control rates of $10 \%$ and above, prairie dog control was not economically feasible by either the U.S. Forest Service or ranchers. At projections of 3,6,9, and 15-year periods for retreatment, initial prairie dog control costs could not be recovered because discounted costs were greater than discounted benefits for any projected control program length in years. Required initial control of over 7 ha of prairie dog colonies to gain an annual grazing increase of 1 AUM was simply too expensive.

The most realistic projection of annual prairie dog repopulation in the Conata Basin appears to be $30 \%$ of the area initially controlled. Based on this projection, prairie dog control was not economically feasible and required annual maintenance costs exceeded the annual value of grazing increases.

\section{Literature Cited}

Bell, W.B. 1920. Death to the rodents. U.S. Dep. Agr. Yearbook. 1920:421-438.

Bonham, C.D., and A. Lerwick. 1976. Vegetation changes induced by prairie dogs on shortgrass range. J. Range Manage. 29:221-225.

Fagerstone, K.A., H.P. Tietjen, and G.K. LaVoie. 1977. Effects of range treatment with 2,4-D on prairie dog diet. J. Range Manage. 30:57-60.

Goodman, L.A. 1960. On the exact variance of products. J. of the American Statistical Assoc. 55:708-713.

Hansen, R.M., and I.K. Gold. 1977. Blacktail prairie dogs, desert cottontails, and cattle trophic relations on shortgrass range. J. Range Manage. 30:210-214.

Kelso, L.H. 1939. Food habits of prairie dogs. U.S. Dep. Agr. Circ. 529.

Klatt, L.E., and D. Hein. 1978. Vegetative differences among active and abandoned towns of black-tailed prairie dogs. J. Range Manage. 31:315-317.

Merriam, C.H. 1902. The prairie dog of the Great Plains. U.S. Dep. Agr. Yearbook. 1902:257-270.

O'Meilia, M.E., F.L. Knoff, and J.C. Lewis. 1982. Some consequences of competition between prairie dogs and beef cattle. J. Range Manage. 35:580-584.

Schenbeck, G.L. 1982. Management of black-tailed prairie dogs on the National Grasslands. Proc. Great Plains Wildlife Damage Control Workshop. Univ. of Nebraska, Lincoln. 5:207-213.

Snell, G.P., and B.D. Hlavachick. 1980. Control of prairie dogs-the easy way. Rangelands. 2:239-240.

Summers, C.A., and R.L. Linder. 1978. Food habits of the black-tailed prairie dog in western South Dakota. J. Range Manage. 31:134-136.

Taylor, W.P., and J.V.G. Loftfield. 1924. Damage to range grasses by the zuni prairie dog. U.S. Dep. Agr. Bull. 1227.

U.S. Department of Agriculture. 1978. Management of prairie dogs on lands administered by the supervisor of the Nebraska National Forest. Final Forest Service Environmental Statement.

U.S. Department of Agriculture. 1979. South Dakota Crop \& Livestock Reporter. Economics, Statistics, and Cooperatives Service, 1979-9.

U.S. Department of Agriculture, Forest Service. 1980. Economic and social analysis. Forest Service Manual Chapter 1970 (interim).

Uresk, D.W., J.G. MacCracken, and A.J. Bjugatad. 1982. Prairie dog density and cattle grazing relationships. Proc. Great Plains Wildlife Damage Control Workshop. Univ. of Nebraska, Lincoln. 5:199-201.

Uresk, D.W., and A.J. Bjugstad. 1983. Prairie dogs as ecosystem regulators on the northern high plains. Proc. North American Prairie Conf. SW Missouri State Univ., Springfield. 7:91-94.

Vavra, M., R.W. Rice, R.M. Hansen, and P.L.Sims. 1977. Food habits of cattle on shortgrass range in Northeastern Colorado. J. Range Manage. 30:261-263.

Wyoming Crop and Livestock Reporting Service. 1979. Special survey of Wyoming grazing arrangements in 1978. Wyoming Dep. of Agr.

\section{Membership in the Society for Range Management. .}

is open to those engoged in or interested in the study. management. or use of range ecosystems and the intelligent use of all range resources

includes research scientists, ranchers, govemmental concy administrators and technical personnel. teachers, students, and people from the business community

- provides members with two publications-one oriented to research (Journal of Range Management) and the other oriented to practical resource manogement (Rangelands) offers opportunities for face-to-foce exchange of ideas at local, national. and intemational meetings of the Society.

Dues vary according to type of membership and geographical section. For application forms and additional information. contact the:

Sociely for Ranoe Manopement

2760 West Fifth Avenue

Denver, Colorodo 80204

(303) 571-0174 